\title{
$\nabla$
}

\section{Linear IgA Dermatosis associated with ulcerative colitis: complete and sustained remission after total colectomy}

\author{
Dermatose bolhosa por IgA linear associada a retocolite ulcerativa: remissão \\ completa e sustentada após colectomia total
}

Thiago Jeunon de Sousa Vargas ${ }^{1}$

Luiza Tavares dos Santos ${ }^{3}$

Ana Luisa Bittencourt Sampaio Jeunon Vargas ${ }^{5}$

\author{
Mônica Fialho \\ Palmira Assis de Jesus Barreto Rodrigues ${ }^{4}$ \\ Maria Auxiliadora Jeunon Sousa ${ }^{6}$
}

\begin{abstract}
Linear IgA dermatosis has been increasingly associated with inflammatory bowel diseases, particularly ulcerative colitis. A 13-year-old male patient with an 11-month history of ulcerative colitis developed vesicles, pustules and erosions on the skin of the face, trunk and buttocks and in the oral mucosa. The work-up revealed a neutrophil-rich sub-epidermal bullous disease and linear deposition of IgA along the dermoepidermal junction, establishing the diagnosis of linear IgA dermatosis. The patient experienced unsatisfactory partial control of skin and intestinal symptoms despite the use of adalimumab, mesalazine, prednisone and dapsone for some months. After total colectomy, he presented complete remission of skin lesions, with no need of medications during two years of follow-up. A review of previously reported cases of the association is provided here and the role of ulcerative colitis in triggering linear IgA dermatosis is discussed.
\end{abstract}

Keywords: Colectomy; Crohn's disease; Dapsone; Immunoglobulin A; Proctocolitis

Resumo: A dermatose bolhosa por IgA linear tem sido crescentemente associada com doenças inflamatórias intestinais, especialmente a retocolite ulcerativa. Relatamos o caso de um adolescente masculino, 13 anos de idade, com retocolite ulcerativa diagnosticada 11 meses antes, que desenvolveu vesículas, pústulas e erosões na pele da face, do tronco e das nádegas e na mucosa oral. A investigação revelou doença bolhosa subepidérmica rica em neutrófilos e deposição linear de IgA ao longo da junção dermoepidérmica, estabelecendo o diagnóstico de dermatose bolhosa por IgA linear. O paciente experimentou controle insatisfatório dos sintomas cutâneos e gastrointestinais apesar do uso de adalimumab, mesalazina, prednisona e dapsona por alguns meses. Após colectomia total, ele apresentou remissão completa das lesões cutâneas, sem necessidade de medicações durante os dois anos de seguimento. Neste artigo, revisamos os casos previamente relatados desta associação e debatemos o papel da retocolite ulcerativa no desencadeamento da dermatose bolhosa por IgA linear. Palavras-chave: Colectomia; Dapsona; Doença de Crohn; Imunoglobulina A; Proctocolite

Received on 17.06.2012.

Approved by the Advisory Board and accepted for publication on 24.08.2012.

* Study conducted at the Investigação em Dermatologia (ID), Rio de Janeiro (RJ), Brazil.

Conflict of interest: None

Financial funding: None

Research Fellowship in dermatopathology at the Ackerman Academy of Dermatopathology, NY. Preceptor of dermatology at the Hospital Geral de Bonsucesso. Dermatologist / Dermatopathologist at Investigação em Dermatologia (ID), Rio de Janeiro (RJ), Brazil.

Dermatologist in private practice - Rio de Janeiro (RJ), Brazil.

Medical student at Grande Rio University (UNIGRANRIO) - Rio de Janeiro (RJ), Brazil.

Graduated in medicine at Rio de Janeiro State University (UERJ) - Medical resident in Dermatology at the Hospital Federal de Bonsucesso (HFB) - Rio de Janeiro (RJ), Brazil.

Masters Degree in internal medicine/dermatology at Rio de Janeiro Federal University (UFRJ). Private practice - Rio de Janeiro (RJ), Brazil.

Research Fellowship in dermatopathology at New York University. Medical Director at Investigação em Dermatologia (ID) - Rio de Janeiro (RJ), Brazil.

(C)2013 by Anais Brasileiros de Dermatologia 


\section{INTRODUCTION}

Linear IgA dermatosis (LAD) is a rare acquired autoimmune bullous disease of unknown etiology, unrelated to gluten-sensitive enteropathy, that affects both adults and children, being also known as chronic bullous dermatosis of childhood (CBDC) in the latter age group. Clinical manifestations are broad, ranging from urticarial, annular or polycyclic reddish patches to small clustered vesicles, tense blisters or large eroded areas. New vesicles may arise around healed blisters, giving rise to the "cluster of jewels" pattern. Mucosal involvement occurs in up to $80 \%$ of cases. ${ }^{1}$ Histopathology reveals a sub-epidermal cleavage and a neutrophil-rich superficial dermal inflammatory infiltrate. In LAD, there is a tendency for neutrophils to be disposed singly along the basal layer of the epidermis, but dermal papilla microabscesses may be possibly found. ${ }^{1}$ Actually there is a significant overlap between the histopathologic features of LAD, DH, bullous lupus erythematosus, some drug eruptions and rare forms of bullous pemphigoid. Direct immunofluorescense studies are therefore the goldstandard method for diagnosis of LAD, through visualization of the characteristic linear deposition of IgA along the dermoepidermal junction. We report a case of LAD associated with ulcerative colitis (UC), which was resistant to medical therapy and the patient underwent complete and sustained remission after total colectomy.

\section{CASE REPORT}

A 13-year-old boy sought dermatological consultation because of itching skin lesions lasting one month. He had had UC diagnosed 11 months earlier and was in continuous use of adalimumab, mesalazine and prednisone $(10 \mathrm{mg} / \mathrm{d})$. On physical examination, erosions with some peripherally disposed vesicles over a reddish background on the forehead and glabella were seen (Figure 1). Some impetigo-like pustular lesions were found on the chin and around the nose. There was also oral involvement, some crusted clustered papules in the precordium, and some large erosions with hemorrhagic exudate in the back, lumbar region and buttocks (Figures 2 and 3). In the intergluteal region, a large eroded plaque covered by a whitish membrane was observed (Figure 4). The patient denied use of any medication previously associated to drug induced-LAD such as vancomycin, penicillin, ceftriaxone, metronidazole, captopril, phenytoin, diclofenac, somatostatin, amiodarone, lithium, cefamandole, cyclosporin, interleukin-2, interferon- $\gamma$ etc. ${ }^{1}$ Histopathology revealed a subepidermal blister and a superficial inflammatory infiltrate consisting of neutrophils arranged in collections on dermal papillae (Figures 5 and 6). Direct immunofluo-

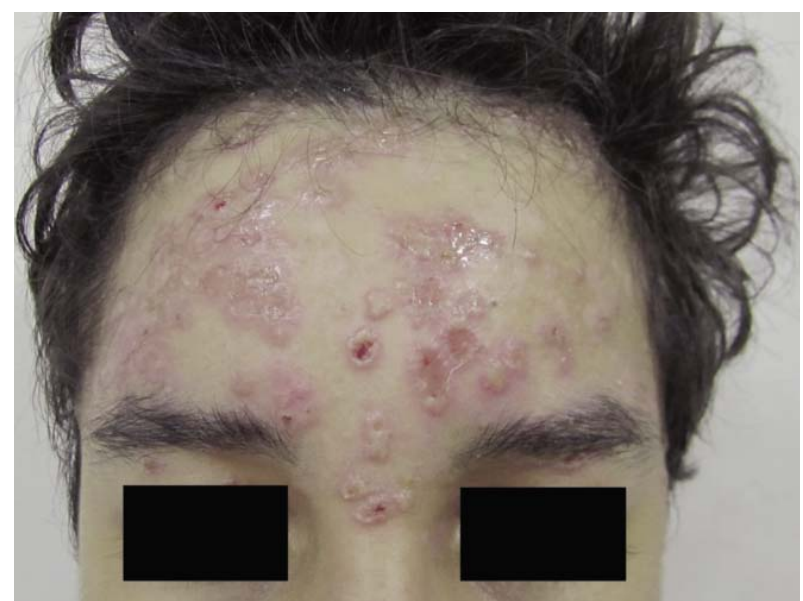

FIGURE 1: Linear IgA dermatosis. Erosions and peripherally-disposed vesicles over a reddish background on the forehead and glabella

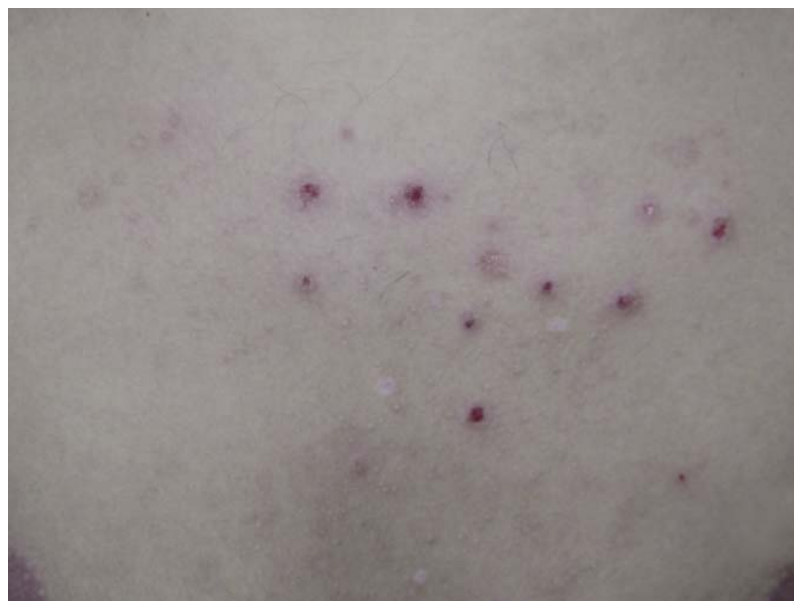

FIGURE 2: Linear IgA dermatosis. Some crusted clustered papules in the precordium

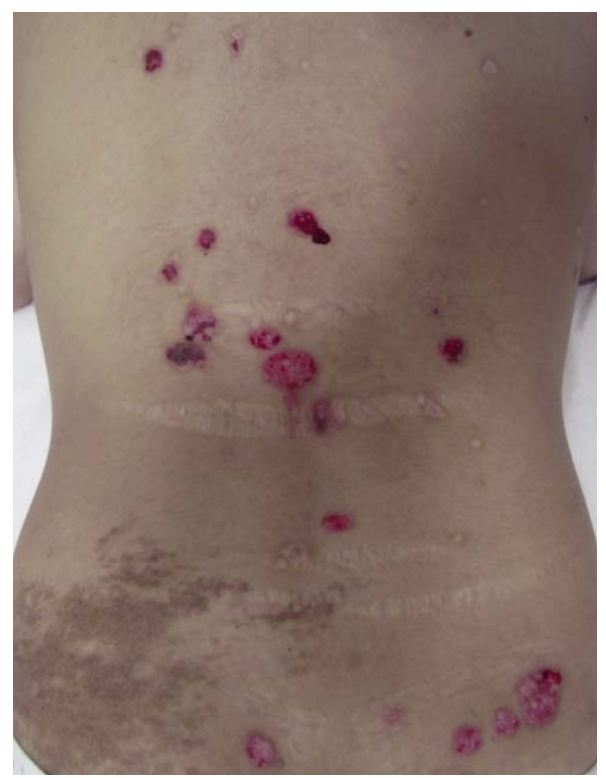

FIGURE 3:

Linear IgA dermatosis. Large erosions with hemorrhagic exudate in the back and lumbar region 


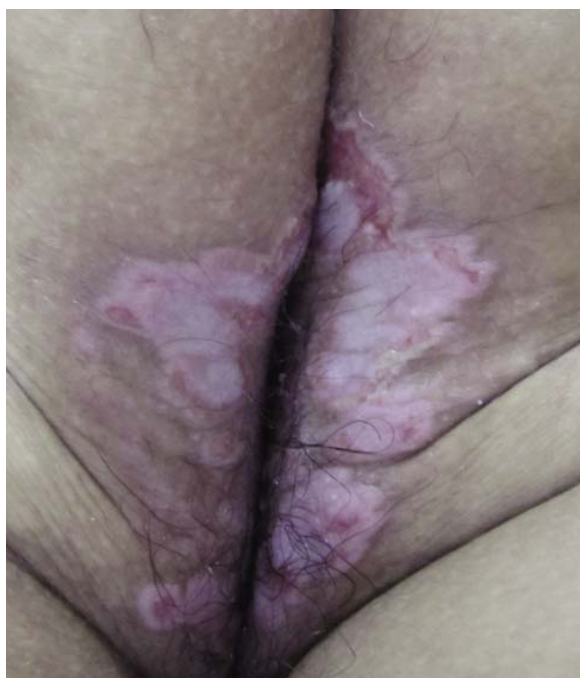

FIGURE 4: Linear $\operatorname{Ig} \mathrm{A}$ dermatosis. Eroded plaque recovered by a whitish exudate in the perianal region

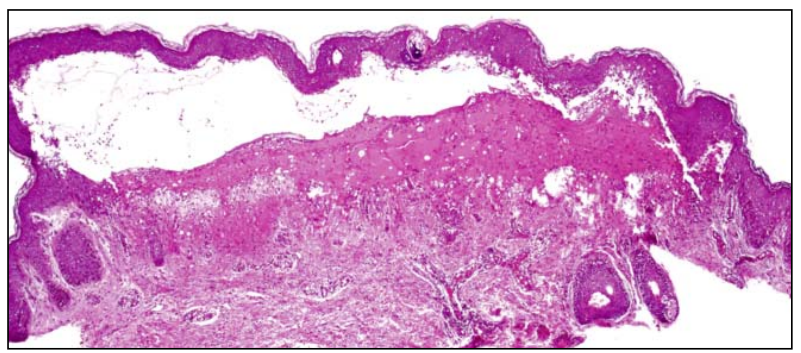

FIGURE 5: Linear IgA dermatosis. Subepidermal blister. (H \& E, 40x)

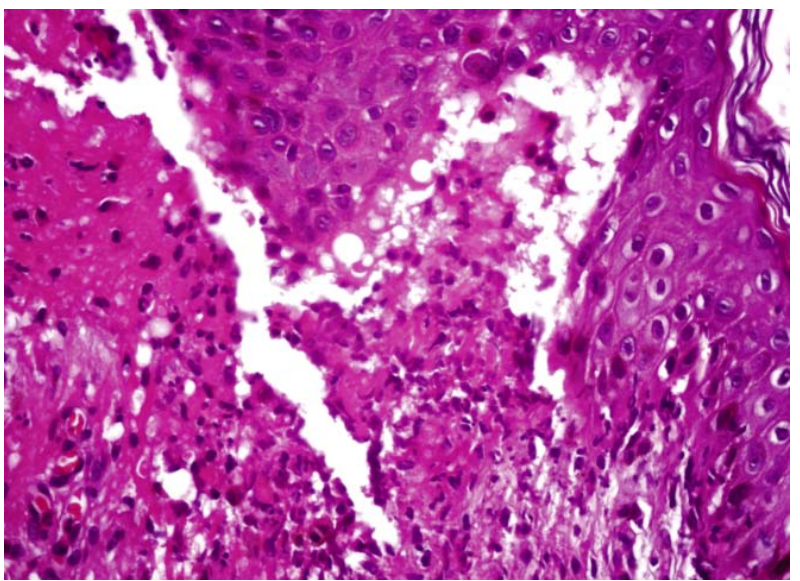

FIGURE 6: Linear IgA dermatosis. Subepidermal blister and inflammatory infiltrate rich in neutrophils with some papillae microabscesses

rescense of perilesional skin depicted a strong linear deposition of IgA along the basement membrane and a focal granular positiveness of C3 (non-specific finding) (Figure 7). IgG, IgM and fibrinogen were negative. The diagnosis of LAD was therefore established and treatment with dapsone $50 \mathrm{mg}$ /day started. In two weeks there was regression of all the skin lesions, leaving only erosions inside the mouth, which were handled

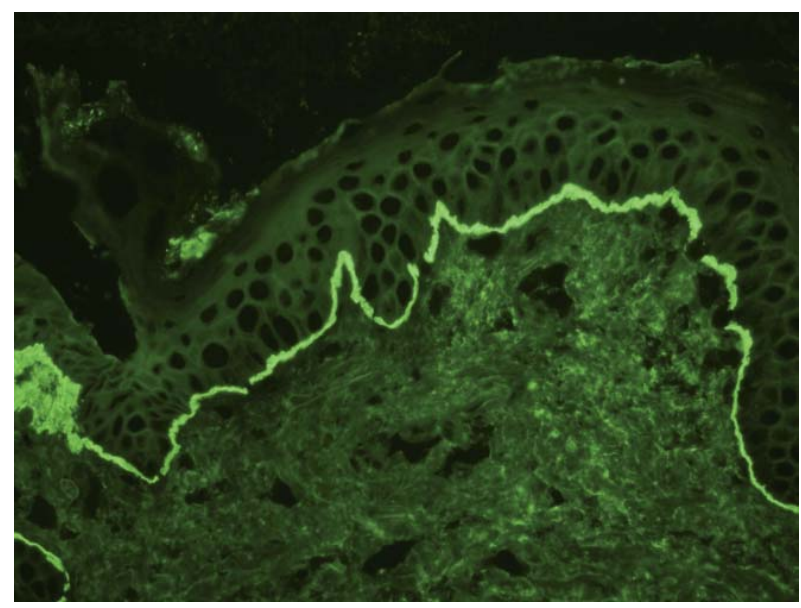

FIGURE 7: Direct immunofluorescense of the skin. Strong linear deposition of IgA along the basement membrane

with triancinolone acetonide $0.1 \%$ ointment. At this point in time oral prednisone was suspended. One month later there was a relapse of perineal and intergluteal lesions, with bleeding. Oral prednisone was reinitiated in the dose of $20 \mathrm{mg} /$ day. A new attempt of tapering prednisone resulted again in a worsening of the skin lesions and the dose of dapsone was increased to $100 \mathrm{mg} / \mathrm{d}$. LAD remained partially but unsatisfactorily controlled over the next 2.5 months, when the patient underwent total colectomy with ileorectal anastomosis for UC and experienced a substantial improvement of skin lesions, allowing reduction of prednisone and dapsone to $10 \mathrm{mg}$ and $50 \mathrm{mg}$ every other day, respectively. After 3 months, the patient returned with complete remission of both LAD and UC and all medications were suspended. There was no relapse in two years of follow-up.

\section{DISCUSSION}

The association of LAD and inflammatory bowel diseases (IBDs) has been increasingly reported in the recent literature. The first case was reported in 1988, concerning a patient with Crohn's disease, and the association of LAD with UC was documented for the first time in 1992., ${ }^{2,3}$ In 1993, Handley et al reported a case of a 12-year-old boy with UC and LAD refratory to prednisone, cyclosporin and talidomide, who had been previously submitted to colectomy because of a toxic megacolon. He experienced complete remission of skin lesions after resection of the remaining diseased rectal stump. ${ }^{4}$ In a British cohort with 70 patients of LAD, concurrent UC was found in 5 patients $(7.1 \%)$, although the estimated prevalence of UC in the United Kingdom is actually only $0.05 \% .{ }^{5}$ We found 23 previously-reported cases of LAD associated with IBDs during our bibliographical research. ${ }^{2-17}$ In all but one case, 
IBD preceded LAD over periods ranging from a few weeks to 43 years. 12 The underlining IBD was UC in 20 cases and Crohn's disease in three. In two cases of $\mathrm{UC}$, there was complete remission of LAD after total colectomy, and in a further two after ressection of the remaining diseased rectal stump in patients previously submitted to colectomy with rectum preservation. ${ }^{4,10,11,16}$ In three cases, LAD remained active after colectomy: two were indicated for treatment of colon adenocarcinoma and one because of toxic megacolon. ., $^{5}$ The rectum stump was preserved in one of these cases, but in the other two the surgery was not sufficiently detailed. In a single case, a close relationship between the activity of UC and LAD was documented, with healing of skin lesions in the event of Ulcerative Colitis Activity Index (UCAI) being under 180, and relapse when it was above $190 .{ }^{15}$ The etiology and pathogenicity of the association between IBDs and LAD is still not completely clear. It is known that patients with UC have a higher number of IgA and IgG-producing lym- phocytes in the colon mucosa. In vitro studies revealed that B-lymphocytes from bowel mucosa of UC patients produce less total IgA than controls, but secrete more monomeric IgA (specially IgA-1). ${ }^{18,19}$ LAD is a disease mediated by monomeric IgA- $1 .^{20}$ It is possible that the immunologic disturbance in patients of UC reflects an alteration in the process of antigenic presentation, resulting in an abnormal production of $\operatorname{IgA}-1$ with cross-reactiveness to antigens of lamina lucida and sub-lamina densa in genetically susceptible patients. Despite the lack of populational studies calculating the relative risk of LAD in patients with $\mathrm{UC}$, the available evidence strongly suggests a significant association, with UC playing an important role in the development of LAD. The present report is the fifth in which LAD abated after surgical treatment for UC, indicating that the colon/rectum might be the source of antigenic stimulation in these cases, driving the autoimmune response and leading to the production of immunoglobulins against normal self-peptides. $\square$

\section{REFERENCES}

1. Egan CA, Zone JJ. Linear IgA bullous dermatosis. Int J Dermatol. 1999;38:818-27.

2. Barberis C, Doutre MS, Bioulac-Sage P, Pompougnac E, Beylot C, Quinton A. Linear IgA bullous dermatosis associated with Crohn's disease. Gastroenterol Clin Biol. 1988;12:76-7.

3. Tomasini D, Bonfacini V, Berti E. Ulcerative colitis and linear IgA disease of adults. Report of a case. Eur J Dermatol. 1992;2:496-9.

4. Handley J, Shields M, Dodge J, Walsh M, Bingham A. Chronic bullous disease of childhood and ulcerative colitis. Pediatr Dermatol. 1993;10:256-8.

5. Paige DG, Leonard JN, Wojnarowska F, Fry L. Linear IgA disease and ulcerative colitis. Br J Dermatol. 1997;136:779-82.

6. Cowan CG, Lamey PJ, Walsh M, Irwin ST, Allen G, McKenna KE. Linear IgA disease (LAD): immunoglobulin deposition in oral and colonic lesions. J Oral Patho Med. 1995;24:374-8.

7. De Simone C, Guerriero C, Pellicano R. Linear IgA disease and ulcerative colitis. Eur J Dermatol. 1998:8:48-50.

8. Chi HI, Arai M. Linear IgA bullous dermatosis associated with ulcerative colitis. J Dermatol. 1999;26:150-3.

9. Porter WM, Hardman CM, Leonard JN, Fry L. Sarcoidosis in a patient with linear IgA disease. Clin Exp Dermatol. 1999;24:67-70.

10. Egan CA, Meadows KP, Zone JJ. Ulcerative colitis and immunobullous disease cured by colectomy. Arch Dermatol. 1999;135:214-5

11. Walker SL, Banerjee P, Harland CC, Black MM. Remission of linear IgA disease associated with ulcerative colitis following panproclocolectomy. $\mathrm{Br} \mathrm{J}$ Dermatol. 2000;143:1341-2

12. Keller AS, Bouldin MB, Drage LA, Hauser SC, Davis MD. Linear IgA bullous dermatosis: an association with ulcerative colitis versus renal cell carcinoma. Dig Dis Sci. 2003;48:783-9.

13. Birnie AJ, Perkins W. A case of linear IgA disease occurring in a patient with colonic Crohn's disease. Br J Dermatol. 2005;153:1050-2.

14. Fernandez-Guarino M, Saez EM, Gijon RC, Garcia BP, Olasolo PJ. Linear IGA dermatosis associated with ulcerative colitis. Eur J Dermatol. 2006;16:692-3.
15. Taniguchi T, Maejima H, Saito N, Katsuoka K, Haruki S. Case of linear IgA bullous dermatosis-involved ulcerative colitis. Inflamm Bowel Dis. 2009;15:1284-5.

16. Caldarola G, Annese V, Bossa F, Pellicano R. Linear IgA bullous dermatosis and ulcerative colitis treated by proctocolectomy. Eur J Dermatol. 2009;19:651.

17. Klein A, Wenzel SM, Messmer EM, Landthaler M, Vogt T. Linear IgA disease with ocular involvement associated with ulcerative colitis. Hautarzt. 2010;61:55-7.

18. MacDermott RP, Nash GS, Bertovich MJ, Mohrman RF, Kodner IJ, Delacroix DL, et al. Altered patterns of secretion of monomeric $\lg A$ and $\lg A$ subclass 1 by intestinal mononuclear cells in inflammatory bowel disease. Gastroenterology. 1986;91:379-85.

19. Selby WS, Janossy G, Bofill M, Jewell DP. Intestinal Lymphocytes subpolulation in Inflammatory bowel disease: an analyses by immunohistochemical and cell isolation techniques. Gut. 1984;25:32-40.

20. Wojnarowska F, Bhogal BS, Black MM. Chronic bullous disease of childhood and linear $\lg \mathrm{A}$ disease of adults are $\lg \mathrm{A} 1$-mediated diseases. $\mathrm{Br} \mathrm{J}$ Dermatol. 1994;131:201-4.

How to cite this article: Vargas TJS, Fialho M, Santos LT, Rodrigues PAJB, Vargas ALBSJ, Jeunon-Sousa MA. Linear IgA Dermatosis associated with ulcerative colitis: complete and sustained remission after total colectomy. An Bras Dermatol. 2013;88(4):600-3. 